\title{
STRUKTUR EPISTEMOLOGI PANCASILA DAN ETOS SAINS DALAM AL-QUR'AN: Suatu Upaya Integrasi, Interkoneksi dan Internalisasi
}

\author{
Wendi Parwanto, Sadari \\ UIN Sunan Kalijaga Yogjakarta | INISA Tambun-Bekasi \\ wendipurwanto@01gmail.com | arifahmikhan@gmail.com
}

\begin{abstract}
The (field) difference (in scope) between theocentric Qur`an, the philosophical Pancasila, and the Science Ethics is scientific in nature becomes an interesting subject to be studied further, especially how to integrate, connect, and internalize those three values in reality. This article offers an alternate way to look up this widely discussed theme/topic using Amin Abdullah's theory, that is, integration-interconnection theory. Added with the concept of internalization, this article aims at actualizing the values of al-Qur'an, Pancasila, and Ethos Science. Since integration-interconnection are not enought to be applied in studying the values, there must be an internalization effort as well so that the velues of all three can be applied and embraced in the society.
\end{abstract}

Keywords: Al-Qur`an; Pancasila; Ethics; Integration-Interconnection

\begin{abstract}
Abstrak
Perbedaan ruang lingkup antara al-Qur`an yang bersifat teosentris, Pancasila yang bersifat filosofis dan Etos Sains yang bersifat sainsifis menjadi suatu yang menarik untuk dikaji lebih jauh, terutama bagaimana meng-integrasikan, menginterkoneksikan dan meng-internalisasikan nilai-nilai ketiganya dalam realitas. Artikel ini menawarkan cara alternatif untuk mengkaji topik ini lebih jauh, yaitu dengan menggunakan teori integrasi-interkoneksi Amin Abdullah. Dan juga ditambah dengan konsep internalisasi, tujuannya adalah untuk mengaktualisasikan nilai-nilai al-Qur`an, Pancasila dan Etos Sains tidak bisa hanya dengan melakukan integrasi dan interkoneksi saja. Namun, harus ada upaya internalisasi sehingga nilai-nilai ketiganya dapat diaplikasikan dalam realitas kemasyarakatan.
\end{abstract}

Kata Kunci: al-Qur`an; Pancasila; Etos; Integrasi-Interkoneksi 


\section{A. Pendahuluan}

Indonesia merupakan negara yang majemuk, dengan deversitas (keragaman) yang ada, seperti; perbedaan ras, suku, tradisi, budaya, bahasa, dan juga agama. Oleh karena itu, salah satu upaya untuk menjaga keutuhan bangsa dan negara ini adalah dengan bersikap arif dan bijaksana dalam mengelola serta melihat diversitas yang ada. Indonesia sebagai negara kesatuan yang dipayungi oleh ideologi Pancasila-sudah barang tentu setiap aksiologis yang dilakukan idealnya mencerminkan nilai kePancasilaan. Namun di sisi lain, selain sebagai negara kesatuan, Indonesia juga merupakan negara yang mayoritas penduduknya beragama Islam. Dengan kuantitas yang dominan tersebut maka tidak menutup kemugkinan akan menimbulkan reaksi konflik atau benturan ideologi antara ideologi bangsa (Pancasila) dan ideologi agama mayoritas yaitu Islam (al-Qur`an). ${ }^{1}$ Oleh karena itu, untuk meminimalisir terjadinya konflik harus ada semacam moderasi antara al-Qur`an dan Pancasila.

Kemudian secara keseluruhan, tulisan ini tidak hanya mengeksplorasi tentang relasi serta upaya dalam membumisasikan al-Qur'an dan Pancasila, namun juga membahas mengenai keterkaitan antara al-Qur`an dan Etos Sains serta proses pembumisasiannya. Adapun fokus analisis dalam tulisan ini adalah: (a) melihat bagaimana konstruk epistemologis Pancasila dan Etos Sains dalam al-Qur`an, (b) menawarkan kiat aksiologis sebagai suatu alternatif untuk menginternalisasikan nilai al-Qur`an, Pancasila dan Etos Sains dalam realitas kehidupan.

1 Banyaknya organisasi yang berkembang dewasa ini yang ingin mendirikan negara yang berasaskan nilai-nilai Islam, atau ingin mendirikan negara dengan sistem khilafah dengan konsep-konsep yang ditawarkan oleh alQur`an dan hadis-salah satunya adalah Hizbut Tahrir Indonesia (HTI). Masuk pertama kali pada tahun 1980-an di bawah pimpinan Abd. Rahman alBaghdadi. Adapun aktivitasnya yang menonjol di Indonesia saat ini adalah mengorganisir demonstrasi, menyelenggarakan seminar dan diskusi publik, publikasi melalui media, serta silaturrahmi ke berbagai ormas Islam dan pemegang kekuasaan. Dalam perjalanannya HTI sering kali berhadapan dan kerap ditentang oleh gerakan Islam pribumi, salah satunya adalah Nahdlatul Ulama (NU). Lihat. Mohamad Rafiuddin, Mengenal Hizbut Tahrir (Studi Analisis Ideologi Hizbut Tahrir dan NU), Jurnal Islamuna, Vol. 2, No. 1, Juni 2015, 29-30; Syaiful Arif, Kontradiksi Pandangan HTI atas Pancasila, Jurnal Keamanan Nasional, Vol. 2, No. 1, 2016, 19-21. 
Sedangkan teori yang digunakan dalam artikel ini adalah menggunakan teori integrasi dan interkoneksi yaitu sebuah teori yang dapat menjembatani antara dua, atau lebih variabel ilmu yang berbeda, yaitu suatu upaya bagaimana meng-integralkan (menyatukan) dan meng-interkoneksikan (menghubugkan) antara berbagai disiplin ilmu. ${ }^{2}$ Namun, dalam penulisannya mengusung konsepsi tambahan sebagai penguat, yaitu konsep internalisasi, karena dalam proses 'memanusiakan' dan membumisasikan alQur`an, Pancasila dan Etos Sains tidak cukup hanya dengan mengitegralisasikan dan mengkoneksikan antara ketiganya, namun juga harus ada upaya internalisasi, yaitu suatu upaya penghayatan yang melahirkan kesadaran dan kemudian berimplikasi pada suatu tindakan praktis dalam realitas kehidupan.

\section{B. Material Ontologis}

Material ontologis dalam artikel ini mencakup tiga variabel utama, yaitu: al-Qur`an, Pancasila dan Etos Sains. Berikut deskripsi definisi dari ketiga variabel tersebut:

1) Al-Qur'an

Secara etimologis kata al-Qur`an adalah derivasi dari kata qara'a-yaqra'u-qur'anan yang bermakna 'mengumpulkan atau kumpulan'. Kemudian al-Qira'ah (bacaan) adalah kumpulan huruf dan kata dalam suatu susunan tertentu. ${ }^{3}$

${ }^{2}$ Teori ini merupakan teori yang diproklamirkan oleh Prof. M. Amin Abdullah, yang sekarang dijadikan sebagai salah satu icon visi UIN Sunan Kalijaga, Yogjakrata. Lihat. Siswanto, Perspektif Amin Abdullah Tentang Integrasi Interkoneksi dalam Kajian Islam, Jurnal Teosofi, Vol. 3, No. 2, Desember, Institut Keislaman Abdul Faqih, Gersik, 382.

${ }^{3}$ Al-Qur'an mendefinisikan dirinya sebagai "kumpulan dan bacaan" seperti yang dimuat dalam QS. al-Qiyamah (75): 17-18. Lihat beberapa diversitas definisi al-Qur'an secara etimologis dalam: Manna' Khalil Al-Qaththan, Mabahits fi 'Ulum al-Qur'an (Riyadh: Ma'syurat al-'Ashr al-Hadits, 1973), 20 ; Az-Zarqani, Manahil al-'Irfan fi 'Ulum al-Qur'an, jilid . I (Beirut: Dar Fikr, 1988), 14; Al-Qurtubi, Al-Jami' li Ahkam al-Qur'an (Beirut: Ar-Risalah, 2006), 425; Masjfuk Zuhdi, Pengantar Ulumul Qur'an (Surabaya: Bina Ilmu, 1993), 2. 
Sedangkan secara terminologis-Manna al-Qaththan memberikan batasan tertentu sebagai gambaran yang dimaksud yaitu adanya al-Qur`an tersebut adalah dapat disaksikan dengan indera manusia, terdeskripsikan dalam pengertian 'tertulis dalam mushaf dan atau dapat dibaca dengan lisan. Dan batasan inilah kemudian bisa dipahami berbagai definisi yang diuraikan oleh para ulama. ${ }^{4}$

Secara umum para ulama mendefinisikan al-Qur'an sebagai "Kalam Allah yang diturunkan kepada Nabi Muhammad Saw yang dinilai ibadah bagi yang membacanya". 5 Adapun tambahan lain dalam mendefinisikan al-Qur'an yang juga dibubuhi oleh para ulama di antaranya seperti: al-mu'jiz (yang melemahkan atau sebagai mu'jizat), bi wasithati Jibril (melalui perantara malaikat Jibril), yang diriwayatkan/disampaikan kepada kita secara mutawatir, dengan bahasa Arab, dan dimulai dari surat al-Fatihah dan dikahiri dengan surat an-Nas. ${ }^{6}$

2) Pancasila

Secara etimologis, Pancasila berasal dari bahasa Sanskerta yaitu: Panca dan Sila. Panca berarti lima, sedangkan sila berarti dasar, sendi atau unsur. Jadi, Pancasila berarti lima dasar, lima sendi atau lima unsur. ${ }^{7}$ Term Pancasila awalnya terdapat dalam teks kepustakaan Buddha di India. Ajaran Buddha yang bersumber dari kitab suci Tri Pitaka, yang terdiri dari tiga kitab besar, yaitu : Suttha Pitaka, Abhidama Pitaka, dan Vinaya Pitaka. Di dalam ajaran Buddha terdapat ajaran moralitas untuk mencapai nirvana melalui samadhi, dan setiap golongan berbeda kewajiban moralnya. Ajaran moral tersebut antara lain: Dasasila, Saptasila, dan Pancasila. ${ }^{8}$

\footnotetext{
${ }^{4}$ Manna' Khalil Al-Qaththan, Mabahits fi 'Ulum al-Qur'an.., 20.

${ }^{5}$ Ulama sepakat tentang definisi al-Qur'an secara terminologis di atasmaksudnya adalah definisi tersebut selalu dimuat atau dihadirkan dalam setiap mendefinisikan al-Qur’an. Sedangkan tambahan-tambahan yang lain dalam mendefinisikan al-Qur`an, para ulama berselisih pendapat.

${ }^{6}$ Mukhotob Hamzah, Studi Al-Qur`an Komprehensif (Yogjakarta: Gema Media, 2003), 1-2. Lihat juga muqaddimah Az-Zamakhsyari, Tafsir alKasysyaf 'an Haqa 'iq at-Tanzil wa 'Uyun 'an Aqawil fi Wujuh at-Ta'wil, jilid I (Riyadh: Maktab al-'Abaikan, 1998), 95.

7 Asep Sulaiman, Pancasila dan Kewarganegaraan (Bandung : Arfino Raya, 2015), 13.

8 Kaelan, Pendidikan Pancasila Yuridis Kenegaraan (Yogjakarta: Paradigma, 1999), 79.
} 
Pancasila secara historis-terminologis, pada tanggal 1 Juni 1945-Soekarno berpidato secara lisan (tanpa teks) mengenai gagasan perumusan dasar negara Indonesia. Di dalam pidatonya tersebut, Soekarno mengusulkan nama dasar negara Indonesia yaitu "Pancasila", yang berarti lima dasar-hal ini bedasarkan usulan dari temannya (seorang ahli bahasa) yang tidak ia sebutkan namanya. Pada tanggal 17 Agustus 1945, Indonesia memproklamirkan kemerdekaannya, dan keesokan harinya (18 Agustus 1945), di sahkan Undang-Undang Dasar 1945 temasuk pembukaan UUD'45 yang di dalamnya memuat isi rumusan lima prinsip sebagai dasar negara yang disebut Pancasila. ${ }^{9}$

3) Etos Sains

Etos berarti pandangan hidup yang khas dari suatu golongan sosial. Etos berasal dari bahasa Yunani (etos) yang memberikan arti sikap, kepribadian, watak, karakter, serta keyakinan atas sesuatu. Sikap ini tidak saja dimiliki oleh individu, tetapi juga oleh kelompok bahkan masyarakat. ${ }^{10}$

9 Perumusan konsep lima dasar dalam Pancasila tidak langsung bisa diterima oleh beberapa tokoh waktu itu, masing-masing dari mereka menyampai rumusannya sendiri; seperti Moh. Yamin, Soepomo dan Soekarno-ketiga memiliki rumusan butir-butir Pancasila tersendiri pada saat melakukan pidato. Kemudian sebagai upaya merangkul beberapa usulan konsep lima dasar yang telah dieksplorasi oleh beberapa tokoh tersebut, maka pada tanggal 22 Juni 1945 dibentuk Piagam Jakarta, yang yang biasa dikenal perumusan Pancasila oleh sembilan tokoh nasional (Paniti Sembilan: Soekarno (ketua), Moh. Hatta (wk. ketua), dan anggotanya; Ahmad Soebardjo, Moh. Yamin, K.H. Wahid Hasyim, Adb. Kahar Moezakir, Abikoesno Tjokrosoejoso, H. Agus Salim, dan Alexander Andrie Maramis). Dari hasil rumusan tersebutjuga masih terdapat ketidak-setujuan dari salah satu tokoh yaitu A.A. Maramis, bahwa dalam sila pertama yang dirumuskan dikatakan bahwa "Ketuhanan dengan kewajiban menjalankan syari'at Islam bagi pemeluk-pemeluknya". Maka fase berikutnya-dengan pertimbangan pluratias masyarakat di Indonesia, maka dirumuskan dan disepakati sila pertama tersebut menjadi "Ketuhanan yang Maha Esa". Dan lima dasar yang disepakati inilah-yang saat sidang PPKI pada tanggal 18 Agustus 1945 ketika mengesahan UUD 1945 yang memuat Pancasila dalam pembukaannya. Lihat Asep Sulaiman, Pancasila dan Kewarganegaraan., 13-17; Ambiro Puji Asmasroini, Menjaga Eksistensi Pancasila dan Penerapannya Bagi Masyarakat di Era Globalisai, Jurnal Pancasila dan Kewarganegaraan, Vol. 1, No. 2 Januari 2017, 51.

${ }^{10} \mathrm{https} / / /$ id.wikipedia.org/wiki/Etos-diakses Senin, 08 Oktober 2018. Pukul 20: 06 WIB. 
Dalam Kamus Besar Bahasa Indonesia etos adalah pandangan hidup yang khas dari suatu golongan sosial. ${ }^{11}$ Secara terminologis kata 'Etos', mengalami perubahan makna yang meluas. Digunakan dalam tiga pengertian berbeda yaitu:

a) Suatu aturan umum atau cara hidup.

b) Suatu tatanan aturan perilaku.

c) Penyelidikan tentang jalan hidup dan seperangkat aturan tingkah laku.

Dalam pengertian lain, Etos dapat diartikan sebagai thumuhat yang berkehendak atau berkemauan yang disertai semangat yang tinggi dalam rangka mencapai cita-cita yang positif. Etos dibentuk oleh berbagai kebiasaan, pengaruh, budaya serta sistem nilai yang diyakininya. Dari kata 'Etos' ini dikenal pula kata etika yang hampir mendekati pada pengertian akhlak atau nilai-nilai yang berkaitan dengan baik buruk moral sehingga dalam etos tersebut terkandung gairah atau semangat yang amat kuat untuk mengerjakan sesuatu secara optimal lebih baik dan bahkan berupaya untuk mencapai kualitas kerja yang sesempurna mungkin. ${ }^{12}$ Sedangkan Sains, dalam Kamus Besar Bahasa Indonesia (KBBI), 'Sains' memiliki beberapa arti: (1) ilmu pengetahuan pada umumnya; (2) pengetahuan sistematis tentang alam dan dunia fisik, termasuk di dalamnya, botani, fisika, kimia, geologi, zoologi, dan sebagainya; ilmu pengetahuan alam; (3) pengetahuan sistematis yang diperoleh dari sesuatu observasi, penelitian, dan uji coba yang mengarah pada penentuan sifat dasar atau prinsip sesuatu yang sedang diselidiki, dipelajari, dan sebagainya. ${ }^{13}$ Jadi berdasarkan definisi Etos dan Sains yang telah dieksplorasi di atas, maka dapat disimpulkan bahwa Etos Sains adalah spirit positif untuk mengembangkan ilmu pengetahuan dalam berbagai bidang atau dalam berbagai disiplin ilmu pengetahuan dengan memperhatikan norma dan kode etik dalam ilmu pengetahuan.

${ }^{11}$ Dalam Kamus Besar Bahasa Indonesia-kata etos disandingkan dengan dua variabel: (1) Etos Kebudayaan, yaitu sifat, nilai, dan adat-istiadat khas yang memberi watak kepada kebudayaan suatu golongan sosial dalam masyarakat; sedangkan (2) Etos Kerja, yaitu semangat kerja yang menjadi ciri khas dan keyakinan seseorang atau suatu kelompok. Kamus Besar Bahasa Indonesia, online (https://kbbi.web.id/etos diakses Senin, 08 Oktober 2018. Pukul 20: 06 WIB.

${ }^{12} \mathrm{https} / / /$ id.wikipedia.org/wiki/Etos-diakses Senin, 08 Oktober 2018. Pukul 20 : 06 WIB.

${ }^{13}$ https://kbbi.web.id/sains-diakses Senin, 08 Oktober 2018. Pukul 20: 06 WIB. 


\section{Material Epistemologis}

Material epistemologis di sini adalah melihat bagaimana konstruk epistem Pancasila dan Etos Sains di dalam al-Qur`an, yaitu dengan melihat bagaimana integrasi dan interkoneksi antara Pancasila dan al-Qur`an serta antara Etos Sains dalam al-Qur`an.

1) Relasi Al-Qur`an dan Pancasila

Al-Qur'an secara normatif-religius dipahami sebagai pedoman hidup bagi umat Muslim, namun secara normatifideologis $^{14}$ al-Qur`an merupakan kitab petunjuk secara universal. ${ }^{15}$ Oleh karena itu, dalam melihat relasi konektifitas antara al-Qur`an dan Pancasila, al-Qur`an tidak bisa diposisikan atau dipahami sebagai kitab suci secara sempit. Al-Qur`an harus dipahami secara luas dalam artian bahwa al-Qur`an mengandung nilai serta ajaran universal bukan hanya bagi umat Muslim, namun juga bagi seluruh umat manusia, tanpa membeda suka, ras, budaya dan agama. ${ }^{16}$

Al-Qur`an sebagai kitab normatif-ideologis, telah tercermin dalam butir-butir pada setiap sila yang terkandung dalam Pancasila. Hal ini mencerminkan bahwa relasi antara alQur`an dan Pancasila telah dirumuskan oleh para perumus Pancasila pada waktu itu. Dan sebagaimana diketahui dari rekaman historis bahwa di antara para perumus sila-sila dalam Pancasila tersebut ada yang beragama non-Muslim ${ }^{17}$, sehingga menyebabkan terjadinya dialektika dalam rancangan Pancasila. Namun, hal itu dapat di atasi dengan berbagai pertimbangan yang ada-terutama melihat realitas masyarakat Indonesia yang bersifat heterogen; multi-etnis, multi-agama, multi-budaya, bahasa dan lain sebagainya. Oleh karena itu, dalam merumuskan Pancasila harus memberikan 'roh' bagi bangsa bukan memberikan 'bencana' bagi bangsa.

\footnotetext{
${ }^{14}$ Yang dimaksud dengan normatif-ideologis di sini adalah ide-ide hukum secara univesal, yang bisa dicapai ketika al-Qur`an diposisikan sebagai kitab petunjuk universal-bukan hanya sebagai kitab suci yang transeden sebagaimana yang diyakini mayoritas umat Islam.

${ }^{15}$ Lihat, QS. al-Baqarah (2): 187.

${ }^{16}$ Abdul Wahid, Al-Qur'an Sumber Peradaban, dalam Jurnal Ushuluddin, Vol. 18, No. 2, Tahun 2012, UIN Sultan Syarif Kasim: Riau, 111.

${ }^{17} \mathrm{Di}$ antara tokoh Panitia Sembilan yang beragama non-Muslim yaitu A.A. Maramis.
} 
Pertanyaannya, apakah di dalam butir-butir Pancasila menghilangkan semangat al-Qur`an? Tentu saja tidak ${ }^{18}$, hal ini membuktikan bahwa para perumus Pancasila, khsususnya panitia dari golongan Muslim saat itu bukan hanya mempertimbangkan kultur serta keragaman masyarakat di Indonesia, namun juga mereka memposisikan al-Qur`an bukan hanya sebagai kitab suci, tetapi melihat serta menjadikan al-Qur`an sebagai sumber nilai secara universal. Oleh karenanya, dalam melihat bagaimana relasi al-Qur`an dan Pancasila, perhatikan kandungan al-Qur`an dalam Pancasila berikut :

Sila Pertama, (Ketuhanan yang Maha Esa) : Dari sila tersebut tersirat bahwa Indonesia mengakui dan menjunjung tinggi kebebasan dalam menganut agama atau keyakinan. ${ }^{19}$ Lalu apakah di dalam al-Qur`an, tidak mecantumkan tentang kebebasan dalam bergama?. Perhatikan QS. al-Baqarah (2): $256^{20}$, QS. al-Kafirun (109): $6 .^{21}$ Dua ayat tersebut cukup representatif membuktikan bahwa al-Qur`an memberikan ruang bagi manusia untuk memilih keyakinannya.

${ }^{18}$ Akan dijelaskan secara lebih rinci pada butir-butir sila dalam Pancalisa dengan mengkorelasikan dengan ayat-ayat al-Qur`an.

${ }_{19}$ Dasar hukum bahwa negara Indonesia menjamin kebebasan beragama bagi rakyatnya dimaut dalam Pasal 28 E ayat 1 dan Pasal 29 ayat 2 dalam Undang-Undang Dasar 1945.

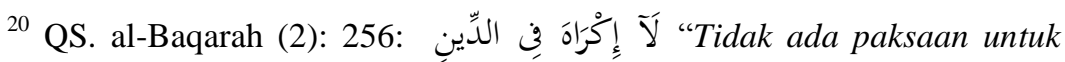
(memasuki) agama (Islam)"

${ }^{21}$ Dalam sebuah riwayat yang bersumber dari Abu Hatim dari Sa'id b. Mina' bahwa Al-Walid b. Al-Mughirah, Al-'Ash b. Wa'il, Al-Aswad b. AlMuthallib, dan Umayyah b. Khalaf bertemu dengan Rasulullah Saw dengan berkata: "Hai Muhammad! Mari kita bersama menyembah apa yang mai sembah, dan kami pun akan menyembah apa yang kamu sembah. Kita bersekutu dalam segala hal, dan engkaulah yang memimpin kami" . Atas dasar percakapan tersebut Allah Swt menurutkan Qs. Al-Kafirun [109]: 1-9-sebagai legalisasi dan penguat bahwa tidak boleh mencampur-adukan akidah dan tidak ada paksaan dalam memeluk agama. Lihat. K.H.Q. Shaleh dan H.A.A. Dahlan, Asbabun Nuzul: Latar Belakang Historis Turunnya Ayat-ayat Al-Qur`an (Bandung: Diponegoro, 2000), 684. 
Hal ini juga dibuktikan dalam realitas praktik dakwah Nabi Muhammad Saw di Madinah yang sangat mengahargai keyakinan umat pribumi saat itu. ${ }^{22}$

Sila kedua, (Kemanusiaan yang Adil dan Beradab): Asas keadilan dan etika banyak sekali dimuat di dalam al-Qur'an, seperti: QS. al-Baqarah (2): 224, QS. Luqman (31): 18, dan QS. al-Hujurat (49): 10, dari ayat-ayat tersebut, jelas bahwa al-Qur`an menghendaki menjunjung tinggi nilai keadilan, adab serta etika dalam setiap dimensi kehidupan.

Sila ketiga, (Persatuan Indonesia): Konsep persatuan dalam al-Qur`an dimuat dalam QS. Ali Imran (3): $200^{23}$, dalam ayat tersebut mengindikasikan bahwa al-Qur'an menghendaki dan menjunjung tinggi nilai kesatuan dalam setiap lini kehidupan.

Karena dengan persatuan dan kesatuan yang solid serta dengan menghargai berbagai diversitas perbedaanlah yang akan dapat menghantar kepada kejayaan dalam kehidupan, hal ini sebagaimana yang telah dipraktikan oleh Nabi Muhammad Saw dan para sahabat serta sejumlah besar kerajaan Islam pada masa klasik.

${ }^{22}$ Salah satu alternatif yang digunakan Nabi Saw untuk membangun peradaban Islam di Madinah yaitu dengan membentuk Piagam Madinah yang ditulis pada tahun $263 \mathrm{M}$ atau tahun ke-2 $\mathrm{H}$. Di antara butir-butir dalam perjanjian Piagam Madinah, yaitu: (1) Kaum Muslimin dan kaum Yahudi hidup secara damai, bebas memeluk dan menjalankan ajaran agamanya masing-masing; (2) Apabila salah satu pihak diperangi musuh, maka mereka wajib membantu pihak yang diserang; (3) Kaum Muslimin dan Yahudi wajib saling menolong dalam melaksanakan kewajiban untuk kepentingan bersama; (4) Muhammad Saw Rasulullah adalah pemimpin umum untuk seluruh penduduk Madinah. Bila terjadi perselisihan di antara kaum Muslimin dan kaum Yahudi, maka penyelesaiannya dikembalikan kepada keadilan Nabi Muhammad Saw sebagai pemimpin tertinggi di Madinah. Jadi dalam butir-butir perjanjian tersebut jelas bahwa Nabi Saw. sangat menjunjung tinggi harkat serta penbedaan masyarakat pada waktu itu, baik dalam budaya dan agama. Ahmad Anas, dkk, Dakwah Nabi Terhadap Masyarakat Madinah Perspektif Komunikasi Antar Budaya, Jurnal Ilmu Dakwah: Academic Journal for Homiletic Studies, Vol. 11, No. 1 Tahun, 2017: UIN Sunan Gunung Djati, Bandung, 63.

${ }^{23}$ QS. Ali Imran (3): 200": Hai orang-orang yang beriman, bersabarlah kamu dan kuatkanlah kesabaranmu dan tetaplah bersiap siaga (di perbatasan negerimu) dan bertakwalah kepada Allah, supaya kamu beruntung." 
Sila keempat, (Kerakyatan yang dipimpin oleh hikmat, kebijaksanaan dalam permusyawaratan/perwakilan). Pokok demokrasi telah dijelaskan dibeberapa tempat dalam al-Qur`an, seperti QS. Ali Imran (3): 159, QS. an-Naml (27): 32 dan QS. Asy-Syura (42): 38. Beberapa ayat tersebut cukup representatif menjelaskan bahwa di dalam al-Qur`an juga terdapat konsepkonsep demokratisasi-yang mana salah satu nilai yang sangat ditekankan yaitu dalam proses pengambilan kebijakan harus diputuskan dengan cara musyawarah agar keputusan yang ditetapkan dapat memberikan maslahat bagi rakyat.

Sila kelima, (Keadilan sosial bagi seluruh rakyat Indonesia): memiliki relasi dengan sila kedua, bahwa dalam realitas kehidupan hendaknya menjunjung tinggi nilai-nilai keadilan. Termasuk dalam hubungan sosial-kemasyarakatan. Dalam al-Qur'an cukup banyak ayat yang berbicara tentang konsep keadilan, di antara seperti QS. an-Nisa` (4) : 58, QS. alMaidah (5): 8, dan QS. an-Nahl (12): 90.

Selain ayat yang telah disebutkan, masih banyak ayat-ayat lain yang memerintahkan untuk berlaku adil dalam kehidupan. Dan hal ini membuktikan bahwa konstruksi epistem Pancasila juga terdapat di dalam al-Qur`an. 
2) Relasi Al-Qur`an dan Etos Sains

Asumsi bahwa al-Qur`an hanya dipandang sebagai kitab suci cenderung mendiskreditkan peran al-Qur`an dalam pengembangan sains atau ilmu pengetahuan. Oleh karena itu, penting melihat bagaimana relasi al-Qur'an dengan ilmu pengetahuan. Banyak ayat di dalam al-Qur'an yang memberikan ultimatum kepada manusia untuk menggunakan akalnya dalam berpikir. Hal ini membuktikan bahwa al-Qur`an memberikan 'ruang bebas' bagi manusia untuk mengembangkan sains dalam realitas kehidupan. ${ }^{24}$

Di antara bukti bahwa al-Qur`an memberikan ladang luas bagi pengembangan ilmu pengetahuan bisa dilihat dari dua aspek: Pertama, al-Qur`an sebagai agen pengetahuan, yang dimaksud alQur'an sebagai agen pengetahuan adalah bahwa al-Qur'an memberikan informasi-informasi dalam berbagai bidang pengetahuan, di antaranya pengetahuan dalam bidang ekonomi, politik, maritim/kelautan dan lain sebagainya. ${ }^{25}$

${ }^{24}$ Perintah al-Qur`an supaya manusia berfilsafat/berfikir dengan kata yatafakkaru-derivasi kata fakkara, termuat dalam beberapa surat di antaranya: QS. Al-Baqarah (2):219, 266, QS. Al-'Imran (3):191; QS. Al-A'raf (7):17; QS. Al-A'raf (7):184; QS. Yunus (10):24; QS. Ar-Ra'd (13):3; QS. an-Nahl (16):11, 44 dan 69; QS. Ar-Ruum (30):8 ; sedangkan dengan redaksi ya'qilunderivasi dari kata 'aqala, dimuat dalam beberapa ayat, di antaranya: Qs. AlBaqarah (2): 44; QS. Ali Imran (3): 65 dan 118; QS. al-An'am (6): 32 dan 151; QS. al-A'raf (7): 169; QS. Yunus (10):5; QS. Hud (11): 51; QS. Yusuf (12): 2 dan 109. Baca Ibnu Mandzur, Lisan al-Arab, Jilid XIII (Qohirah: Dar alHadits, 2009), 85-86.

${ }^{25}$ Perhatiakan Qs. al-An'am (6): 38; artinya: "Tidak kami tinggalkan di dalam Al-Kitab ini sesuatupun (tidak ada satupun yang tidak kami tulis di dalam kitab ini'-Walapun dalam interptretasi ayat tersebut masih terjadi dialektika. Namun, secara literal Allah Swt dan diakui oleh beberapa ulama bahwa memang berdasarkan ayat tersebut bahwa Allah tidak melupakan suatu permasalahkan pun di dalam al-Qur`an-baik dari ilmu ukhrawi maupun ilmu duniawi. 
Jadi, informasi yang didapatkan dari al-Qur`an dapat dieksplorasi dan dielaborasi lebih jauh dengan spirit modernitas saat ini. Kedua, al-Qur`an sebagai legitimasi dari berbagai penemuan sains modern, contoh dalam bidang embriologi-pada 14-15 abad yang lalu al-Qur`an telah berbicara tentang bagaimana proses reproduksi manusia, dan ternyata dengan penemuan sains modern ditemukan koherensi dengan apa yang diwartakan oleh al-Qur'an ${ }^{26}$, dan ini merupakan salah satu bukti keterkaitan antara al-Qur`an dan sains-terutama al-Qur`an sebagai legitimasi dari penemuan sains modern. ${ }^{27}$

${ }^{26}$ Tentang embriologi secara khusus telah banyak ditulis dalam beberapa buku di antaranya yaitu buku yang ditulis oleh Muh. Izuddin Taufiq, Dalil Anfus Al-Qur`an dan Embriologi (Ayat-ayat Tentang Penciptaan Manusia), (Solo: Tiga Serangkai, 2006) dan Kiptiyah, Embriologi dalam Al-Qur'an: Kajian Pada Proses Penciptaan Manusia (Malang: UIN Malang Press, 2007).

27 Banyak buku-buku yang telah ditulis oleh para sarjanwan yang membahas tentang relasi al-Qur'an dan Sains, seperti: Ahmad Fuad Pasya, Rahiq Al-'Ilmi wa Al-Iman, terj. Muhammad Arifin, Dimensi Sains Al-Qur'an (Solo: Tiga Serangkai, 2004); Nadiyah Tharayyarah, Mausu'ah al-I'jaz alQur'ani (Dar al-Yamana, Abi Dhabi, t.t); TIM Kemenag RI dan LIPI, Mengenal Ayat-ayat Sains Di Dalam Al-Qur`an); Ramadhnai, dkk, Al-Qur`an Vs Sains Modern Menurut Zakir Naik (t.tp : Sketsa, t.t); Ridwan Abdullah Sani, Sains Berbasis Al-Qur an (Jakarta: Bumi Aksara, 2015).-Bukan hanya di dalam al-Qur`an, perhatikan juga dalam hadis-banyak hadis yang cenderung bernuansa 'jorok'; seperti hadis tentang "menenggelamkan lalat ke dalam bejana/gelas, apabila ia telah jatuh ke dalam bejana tersebut". Secara akal, hal ini memang tidak logis-mana mungkin lalat yang lumrahnya dipandang sebagai salah satu binatang yang jorok, pembawa penyakit dan sejumlah asumsi negatif lainya. Namun pada kenyataannya, dengan penemuan sains modern bahwa menenggelamkan lalat ke dalam bencana tersebut memiliki arti tersendiri, khusunya dalam hal panawar racun yang ada lalat tersebut. Yunita Kartika Sari, Studi Hadis Tentang Lalat, Skripsi Jurusan Ilmu Al-Qur`an dan Tafsir, UIN Syarif Hidayatullah, Jakarta, 2017. Kemudian DR. H. Abdul Mustaqim (Ketua Prodi Ilmu Al-Qur`an dan Tafsir, UIN Sunan Kalijaga, Yogjakarta)-menambahkan bahwa sains juga bisa dimasukan sebagai salah satu kriteria alternatif dalam melihat serta menilai kualitas ke-shahihan suatu hadis di era modern saat ini, karena walaupun derajat serta kualitas hadis itu shahih, nanapum jika bertentangan dengan mashlahah an-Nas, salah satunya bagi kesehatan, maka hadis tersebut tidak bisa digunakan. Oleh karena itu di sinilah peran pentingnya pengembangan sains dan teknologi modern; Abdul Mustaqim dalam Kuliah Hermeneutika Hadis, Prodi Studi Al-Qur`an dan Hadis, UIN Sunan Kalijaga, 2017. 


\section{Material Aksiologis}

Setelah mengeksplorasi tentang relasi antara Pancasila dan

Etos Sains dengan al-Qur`an. Maka selanjutnya penting dikemukakan tentang bagaimana upaya aksiologis untuk menginternalisasikan nilai-nilai al-Qur`an, Pancasila dan Etos Sains dalam realitas kehidupan. Berikut beberapa tawaran penulis sebagai suatu altertanatif proses membumisasikan al-Qur`an, Pancasila, dan Etos Sains dalam realitas.

1) Spirit Al-Qur`an Sebagai Basis Kemajuan

Untuk melihat bagaimana al-Qur`an memotivasi dan memberikan stimulasi kepada manusia, perhatikan dua prinsip berikut:

a) Prinsip Kebebasan Berpikir, Berinovasi, dan Berkreasi

Sebagaimana yang telah dijelaskan pada pembahasan relasi antara al-Qur`an dan Pancasila, demikian juga dalam relasi al-Qur'an dan sains, bahwa al-Qur'an memberikan ruang gerak yang cukup luas dalam berekspresi, baik itu dilakukan secara personal maupun komunal. Jadi jika nilai-nilai alQur`an dapat dipribumisasikan, maka secara otomatis nilainilai Pancasila dan etos sains juga akan tertanam.

Pancasila sebagai landasan ideologi bangsa Indonesia yang pada akhirnya melahirkan landasan konstitusional (UUD) sebagai eksplorasi dan interpretasi dari nilai-nilai yang terkandung di dalam Pancasila. Salah satu bukti bahwa Pancasila mengusung asas kebebasan berpikir, berinovasi dan berkreasi adalah sebagaimana dimuat dalam sila yang kelima bahwa "Pancasila menjamin keadilan sosial bagi seluruh rakyat Indonesia"-"keadilan dalam sila tersebut jika diinterpretasikan lebih jauh maka bukan hanya dalam ranah relasi sosial, namun juga memberikan keadilan bagi rakyat Indonesia untuk menciptakan inovasi dan kreasi bagi kemajuan bangsa. ${ }^{28}$

${ }^{28}$ Di atur dalam Undang-undang No 9 tahun 1998 tentang kemerdekaan menyampaikan pendapat di muka umum, hak kemerdekaan mengemukakan pendapat adalah hak setiap warga negara untuk menyampaikan pikiran dengan lisan, tulisan, dan sebagainya secara bebas dan bertanggung jawab sesuai dengan ketentuan perundang-undangan yang berlaku. 
Demikian juga dalam Etos Sains, sebagaimana yang telah dijelaskan pada relasi al-Qur`an dan sains di atas, bahwa al-Qur'an memberikan peluang untuk meningkatkan pengembangan ilmu pengetahuan dalam berbagai lini kehidupan. Oleh karena itu, menumbuhkan spiritualitas Etos Sains merupakan salah satu bentuk menghidupkan semangat al-Qur`an.

Jadi mempribumisasikan nilai-nilai Pancasila dan Etos Sains, terutama dalam memberikan peluang bagi manusia untuk berinovasi dan berkreasi memiliki relasi yang erat dengan prinsip al-Qur`an. Dalam QS. al-Baqarah (2): $31^{29}$ alQur`an memberikan ruang berpikir, berinovasi dan berkreasi bagi manusia-bahwa Allah Swt menciptakan manusia sebagai pengelola alam. Manusia dimanifestasikan sebagai 'delegasi' Allah di muka bumi, diberikan 'kebebasan' dalam mengekspresikan tindakannya, baik dalam berinovasi dan berkreasi. Oleh karena itu, sebagai makhluk yang telah diberikan wewenang oleh Allah, maka sudah seharusnya kita memanfaatkan segala potensi yang kita miliki untuk memberikan kontribusi dalam realitas kehidupan. ${ }^{30}$

Kemudian, perhatikan lagi dalam QS. Al-'Alaq (96): 15, Allah Swt memulai 'komunikasinya' dengan lafadz 'Iqra', ini membuktikan bahwa Allah Swt menginginkan manusia memiliki sifat sensitivitas yang tinggi dalam memaknai berbagai fenomena yang terjadi dalam realitas, sehingga dari berbagai fenomena tersebut bisa melahirkan suatu ide, gagasan, inovasi serta kreatifitas baru-terutama dalam memberikan sumbangsih bagi peradaban. ${ }^{31}$ Jadi berdasarkan dua ayat yang dikutip di atas, bahwa al-Qur`an sangat mengapresiasi semangat manusia untuk berinovasi dan berkreasi sesuai dengan bidang dan minat yang dimiliki.

${ }^{29}$ QS. al-Baqarah (2): 31-dalam ayat tersebut terekam tentang dialogis antara Allah dan Malaikat dan salah satu tujuan Swt menciptakan manusia adalah untuk memakmurkan bumi.

${ }^{30}$ Wendi Parwanto dan Ridwan Rosdiawan, Menggali Akar-akar Material Dakwah Lingkungan Hidup, Jurnal Al-Hikmah, IAIN Pontianak, Vol. 10, No. 1, 2016, 51-52. Lihat juga. M. Quraish Shihab, Tafsir Al-Misbah: Pesan, Kesan dan Keserasian Al-Qur'an, Jilid. I (Jakarta: Lentera Hati, 2002), 172173 dan Membumikan Al-Qur'an: Fungsi dan Peran Wahyu dalam Kehidupan Masyarakat (Bandung: Mizan, 1992), 460.

${ }^{31}$ Colle Said, Paradigma Pendidikan dalam Perspektif Surat Al- 'Alaq (96): 1-5, Jurnal Hanafa: Jurnal Studi Islamika, Vol. 13, No. 1, 2016: UIN Alauddin, Makassar, 108-109. 
b) Prinsip Pengembangan Potensi: Personal dan Kolektif

Prinsip pengembangan potensi adalah pengeksplorasian dari prinsip kebebasan berpikir, berinovasi dan berkreasi. Jadi dengan potensi-potensi yang dimiliki oleh individu atau kelompok dapat dimanifestasikan dalam realitas. Demikian juga di dalam al-Qur`an, memerintahkan manusia untuk berlomba-lomba dalam melakukan kebajikan, di antaranya yaitu dengan melakukan pengembangan bakat dan minat baik itu secara personal maupun kolektif, ${ }^{32}$ dengan pengembangan bakat dan minat tersebut harapannya akan melahirkan ide-ide serta gagasan baru yang memiliki kontribusi yang baik bagi bangsa, negara serta agama.

Termasuk juga dengan menamkan nilai-nilai Pancasila dan Etos Sains-khususnya dalam pengembangan potensi, maka secara otomatis akan menanamkan nilai Qur`ani dalam realitas praktis. Contoh seorang tentara yang memiliki loyalitas dan semangat nasionalis yang tinggi terhadap negaranya, ia rela mati demi membela serta mempertahankan tanah airnya maka hal tersebut bisa dikategorisasi sebagai jihad, walaupun 'bukan' dalam ranah membela agama Allah. ${ }^{33}$ Demikian pentingnya pengembangan potensi secara kolektif, misal: dalam suatu rumah sakit hanya terdapat satu dokter umum, tanpa ada dokter spesialis maka yang terjadi adalah ketidak-efisienan pelayanan dan penanganan bagi para pasien, maka implikasi jangka panjangnya adalah bisa jadi rumah sakit tersebut akan 'gulung tikar' karena minimnya pelayanan yang diberikan, dan tentang pengembangan potensi secara kelompok ini cukup banyak disignalir oleh al-Qur`an. ${ }^{34}$

${ }^{32}$ Baca Qs. Al-Baqarah (2): 148.

${ }^{33}$ Cinta tanah air di dalam QS. al-Qashash (28): 85 ketika menafsirkan ayat tersebut-Ismail Haqqi Al-Hanafi Al-Khalwathi (w. $1127 \mathrm{H})$ dalam tafsirnya Ruhul Bayan ia mengatakan: terdapat suatu petunjuk atau isyarat bahwa "cinta tanah air sebagian dari iman". Rasulullah Saw (dalam perjalanan hijrahnya menuju Madinah) banyak sekali menyebut kata; "tanah air, tanah air", kemudian Allah Swt mewujudkan permohonannya (dengan kembali ke Makkah), Sahabat Umar r.a berkata; "Jika bukan karena cinta tanah air, niscaya akan rusak negeri yang jelek (gersang), maka sebab cinta tanah air lah, dibangunlah negeri-negeri”. Ismail Haqqi al-Hanafi, Ruhul Bayan, Juz 6 (Beirut: Dar Al-Fikr, t.t), 441-442.

${ }^{34}$ QS. al-Maidah [5]: 2, artinya: "Dan tolong-menolonglah kamu dalam (mengerjakan) kebaikan dan takwa, dan jangan tolong-menolong dalam berbuat dosa dan pelanggaran." 
Oleh karena itu, pengembangan potensi sangat dibutuhkan dalam kehidupan, baik itu pengembangan potensi secara individual maupun kolektif, dan keduanya sama-sama memiliki porsi dan peran masing-masing dalam realitas.

Jadi konsep spiritualitas al-Qur`an berbasis kemajuan terutama dalam hal merealiasasikan dua prinsip di atas, maka jelas terlihat bahwa adanya integrasi dan interkoneksi antara ketiga komponen besar, yaitu; al-Qur`an, Pancasila dan Etos Sains. Jadi, spiritulitas al-Qur`an menjadikan payung nilai bagi Pancasila dan Etos Sains, karena dengan merealisasikan nilainilai al-Qur'an yang berbasis kemajuan maka secara otomatis akan menerapkan nilai-nilai Pancasila dan Etos Sains. Sebagaimana yang telah disinggung di atas bahwa spirit yang termuat di dalam butir-butir Pancasila dan Etos Sains adalah mengandung nilai-nilai Qur`aniyah.

2) Nilai-nilai Al-Qur`an Sebagi Panoptisasi Tindakan

Yang dimaksud dengan nilai-nilai al-Qur`an sebagai panoptisasi tindakan adalah menjadikan al-Qur`an sebagai panoptik (pengontrol) serta payung etika dalam tindakantindakan yang dilakukan. ${ }^{35}$ Demikian juga dalam merealisasikan nilai-nilai Pancasila dan Etos Sains-tentunya ketika manusia merealisasikan atau menjadikan nilai-nilai alQur`an sebagai acuan maka dengan sendirinya nilai-nilai Pancasila dan etos sains juga akan terealisasi. Misal, ketika merealisasikan nilai permusyawaratan di dalam al-Qur`an, ${ }^{36}$ untuk membulatkan dan mendapat suatu mufakat, maka juga termasuk merealisasikan nilai Pancasila, khsususnya sila yang keempat.

${ }^{35}$ Yang dimaksud al-Qur`an sebagai panoptik di sini adalah bukan bahasa al-Qur`an secara literal, namun lebih kepada konsep ideal moral (maqasid alQur`an) dari nilai-nilai yang terkadung di dalam al-Qur`an.

${ }^{36} \mathrm{Di}$ antara ayat-ayat al-Qur`an yang berbicara tentang musyawarah telah dijelaskan dalam footnote pada pembahasan sila keempat di atas. 
Demikian juga dalam Etos Sains, al-Qur`an banyak sekali berbicara tentang spirit untuk meningkatkan kualitas intelektual, perhatikan QS. az-Zumar (39): 9 (berbicara tentang diferensiasi antara kaum intelektual dan nonintelektual), QS. al-Mujadilah (58): 11 (berbicara tentang kemulian orang-orang yang beriman dan memiliki intelektual yang tinggi), QS. at-Taubah (9): 122 (tentang perintah melakukan rihlah intelektual). Ayat-ayat tersebut cukup representatif menunjukkan bahwa dengan merealisasikan nilainilai al-Qur`an secara otomatis akan merealisasikan Etos Sains dalam kehidupan.

Adapun tentang bagaiamana menjadikan nilai-nilai al-Qur`an sebagai panoptisasi dalam kehidupan setidaknya ada dua item yang ditawarkan:

a) Nilai Ketuhanan

Pada sila yang pertama dalam Pancasila (Ketuhanan yang Maha Esa), memberikan penekanan tentang asas keyakinan bahwa dalam realitas kehidupan ada sang pengatur yang Maha Tinggi. Keyakinan yang kuat kepada Tuhan selaku pengatur kehidupan akan melahirkan sifat serta keyakinan bahwa hendaknya setiap prilaku dan tindakan yang dilakukan harus mencerminkan dan memberikan nilai manfaat bagi kehidupan. Karena keyakinan tentang ketelitian pengawasan dari Tuhan akan menyebabkan manusia takut untuk berbuat keburukan. Dalam QS. an-Nisa' (4): 1, QS. alAhzab (33): 52 dan QS. al-Maidah (5): $117 .^{37}$

${ }^{37}$ Dalam ayat-ayat tersebut kata "pengawasan" menggunakan lafadz 'arRaqib-menurut Ibnu Faris menjelaskan bahwa 'ar-Raqib ini menunjukkan makna yang satu, yaitu berdiri (tegak) untuk mengawasi/memperhatikan sesuatu. Ibnu Fariz, Mu’jam maqayis al-Lughah, Jilid. 2 (Beirut: Dar alIslamiyyah, 1990), 353; sedangkan menurut Fairuzzabadiy menjelaskan bahwa 'ar-Raqi secara bahasa berarti pengawas, penunggu dan penjaga. Az-Zabadiy, al-Qamus al-Muhith (Kairo: Dar Ibnu al-Jauzi, t.t), 116; dan menurut Ibnu al'Atsir dan Ibnu Manzhur menjelaskan bahwa nama Allah al-Raqib berarti Maha Penjaga/Pengawas yang tidak ada sesuatupun yang luput dari-Nya. Ibnu Atsir, an-Nihayah fi garib al-Hadits wa al-Atsar, jilid 2 (Beirut: Dar Ma'rifat, 1991), 609; dan Ibnu Mandzur, Lisan al-'Arab, jilid. 1 (Al-Qahirah: Dar alHadits, 2009), 424. 
Jelas menunjukkan bahwa Tuhan akan senantiasa mengawasasi segala tindakan yang dilakukan oleh hambahamba-Nya. ${ }^{38}$ Oleh karena itu, maka wajar jika dalam sila yang pertama dalam Pancasila diletakkan pondasi ketuhanan-sehingga hal tersebut diharapkan mampu menumbuhkan kesadaran manusia untuk senantiasa berhatihati dalam melakukan setiap aksi tindakan. Demikian juga di dalam Etos Sains-banyak manusia cerdas, pintar, memiliki kualitas intelektual yang tinggi, namun sayang dengan kepintarannya tersebut bukan memberikan kontribusi yang positif, malah disalahgunakan dengan hal-hal yang negatif. Oleh karena itu, dalam QS. al-Mujadalah (58): 11 Allah menyandingkan iman dan ilmu, jadi antara iman dan ilmu harus saling berintegrasi karena jika salah satunya diabaikan maka akan menimbulkan suatu ketimpangan.

b) Nilai Kemanusiaan

Al-Qur`an banyak sekali mewartakan tentang pentingnya memperhatikan nilai-nilai kemanusiaan. Misal, dalam QS. al-Maidah (5): 42 (memerintahkan manusia untuk berlaku adil), QS. al-Hujurat (4): 11 (melarang manusia mengolok, mengunjing antar sesama), QS. Abasa (80): 1-10 (tentang perintah untuk ramah kepada orang lain), QS. AlMaidah (4): 2 (tentang saling tolong menolong), QS. AlHujurat (49): 13 (tentang perintah saling menghargai diversitas keragaman dalam kehidupan ; baik itu suku/etnis, budaya, bahasa, agama dan lain sebagainya) dan sederetan nilai-nilai kemanusiaan lainnya yang diwartakan oleh alQur`an. Demikian juga dalam Pancasila, selain sila yang pertama, sila-sila berikutnya (sila 2-5) mencerminkan pentingnya menanamkan nilai-nilai kemanusiaan. Oleh karena itu, ini menunjukkan bahwa antara nilai-nilai alQur`an dan Pancasila saling berintegrasi. Demikian juga dalam Etos Sains, nilai kemanusiaan juga harus diperhatikan. Jika semangat Etos Sains yang tinggi tidak diimbangi dengan pertimbangan nilai-nilai atau aspek sosial-kemanusiaan maka yang terjadi adalah ketimpangan dan dan kemudharatan.

${ }^{38}$ Keyakinan akan ketelitian monitoring dari Tuhan pasti tidak hanya diyakini oleh umat Muslim, namun seluaruh umat manusia yang ada dimuka bumi meyakini akan hal tersebut. Oleh karena itu, dalam setiap melakukan perbuatan atau tindakan hendaknya selalu merasa diawasi oleh Tuhan. 
Salah satu contoh dalam dunia industri, perkembangan sains dalam dunia industri sering menimbulkan isu-isu yang negatif karena ketidakcakapan pihak industri dalam mengelola dan membuang limbah industrinya sehingga menyebabkan pencemaran lingkungan dan meresahkan masyarakat sekitar. Oleh karena itu, di dalam al-Qur'an banyak sekali ayat-ayat yang menerangkan hendaknya perkembangan ilmu pengetahuan harus diimbangi dengan basis agama ${ }^{39}$, sehingga tidak menimbulkan kerugian dan hal-hal negatif lainnya.

3) Konsekuensi Hukum: Antara Hukum Positif dan Hukum Tuhan

Setiap aksi atau tidakan negatif yang dilakukan pasti memiliki konsekuensi hukum, baik itu hukum positif ${ }^{40}$ maupun hukum al-Qur`an. Oleh karena itu, ketika terjadi penyimpangan tindakan baik penyimpangan dalam Pancasila maupun dalam Etos Sains, maka memiliki konsekuensi tersendiri sesuai dengan potensi kejahatan yang dilakukan. Baik itu dari sisi hukum positif maupun dari hukum alQur`an. Untuk melihat lebih jauh tentang realisasi hukum positif dan hukum al-Qur`an perhatikan hal dibawah ini:

a) Hukum Positif Berbasis Al-Qur`an

Tujuan hukum secara universal adalah memberikan efek jera kepada pelakuknya. Namun, realitas yang terjadi bahwa banyak supremasi hukum yang belum memberikan rasa jera dan tidak menumbuhkan kesadaran bagi pelaku kejahatan. Ini membuktikan bahwa kualitas hukum yang diterapkan belum mampu mengubah pola pikir (maindset) serta epistem pelaku kejahatan untuk takut melakukan aksi kejahatannya. Hukum seolah-olah hanya besifat peringatan semantara bukan sebuah peringatan yang mampu serta menyentuh efek jera bagi pelaku. Salah satu contoh di Indonesia, hukum bagi pelaku pemerkosaan, pembunuhan, koruptor dan pelanggaran berat lainnya hanya diganjar dengan hukuman belasan tahun atau puluhan tahun penjara.

${ }^{39}$ QS. al-Mujadilah (58): 11.

${ }^{40}$ Hukum positif yang dimaksud di sini adalah seperti Undang-undang Dasar, Peraturan Presiden, Praturan Pemerintah dan seperangkat supremasi hukum lainnya. 
Sehingga dengan hukuman yang demikian masih banyak pengulangan yang kejahatan yang dilakukan, hal ini membuktikan bahwa kualitas hukum di Indonesia belum menyentuh aspek kesadaran. Al-Qur'an sangat tegas memberikan hukuman bagi pelaku kejahatan berat seperti pembunuhan $^{41}$, perzinaa $^{42}$, pencurian/korupsi. ${ }^{43} \mathrm{Jika}$ hukum yang ditawarkan al-Qur'an dilihat dari sebelah mata maka cenderung menimbulkan asumsi bahwa al-Qur`an atau Islam itu kejam, tidak menghargai hak asasi dan asumsi-asumsi lainnya. Namun, jika ditelaah lebih jauh dan mendalam, mengapa al-Qur'an menawarkan konsekuensi hukum yang demikian-bahwa tujuannya tidak lain adalah untuk memberikan efek jera bagi para pelaku kejahatan. Dan hal inilah yang perlu diterapkan di Indonesia, bagaimana untuk memikirkan, merumuskan, mensosialisasikan serta mengaplikasikan hukum yang memiliki spirit al-Qur`an, yaitu suatu supremasi hukum yang memberikan efek jera bagi pelakunya. Asumsi bahwa perbedaan kultur-budaya Arab dan Indonesia yang tidak sama, ini tidak bisa dijadikan sebagai alasan tentang ketidak-bolehan menerapkan hukum yang berbasis nilai-nilai al-Qur`an di Indonesia. Yang dimaksud dengan menerapkan hukum positif yang berbasis nilai al-Qur`an adalah dengan menciptakan supremasi hukum yang memberikan efek jera bagi pelaku kejahatan serta memberikan edukasi kepada orang lain tentang bahaya serta beratnya hukuman yang akan diterima ketika seseorang melakukan kejahatan. Bentuk-bentuk hukuman yang diberikan tidak harus sesuai dengan apa yang tertera secara literal sebagaimana yang terdapat di dalam al-Qur`an, namun disesuaikan dengan kultur-budaya yang ada. Tetapi semangat al-Qur'an, yaitu memberikan efek jera harus menjadi acuan utama, dalam bahasa lain bahwa hukum al-Qur'an yang diterapkan bukan hukum secara literal, namun secara ideal moral. $^{44}$

${ }^{41}$ QS. al-Baqarah (2): 178

${ }^{42}$ QS. al-Isra' (17): 32; QS. an-Nur (24): 4 dan 23.

${ }^{43}$ QS. al-Maidah (4): 38; QS. al-Baqarah (2): 188 dan QS. al-Anfal (8): 27.

${ }^{44}$ Tentang idel moral ini telah dijelaskan dalam teori Fazlur Rahman: Rahman mengatakan bahwa dalam memahami kadungan al-Qur`an harus mengedepankan nilai-nilai moralitas atau bervisi etis. Nilai-nilai moralitas dalam Islam harus berdiri kokoh berdasarkan ideal moral al-Qur`an, Fazlur Rahman, Islam (New York: Anchor Books, 1966), 28. 
b) Hukum Tuhan Berbasis Ketaatan

Asumsi yang biasanya muncul ketika manusia tertimpa musibah, bencana dan lain sebagainya adalah karena prilaku mereka telah menyimpang dari syari'at. Namun asumsi ini perlu ditinjau kembali, karena tidak menutup kemungkinan bahwa bahaya atau bencana yang menimpa atau terjadi merupakan sunnatullah atau hukum alam yang memang semestinya terjadi, misal seseorang yang tinggal dibawah perbukitan, lalu ketika hujan datang maka seketika itu terjadilah longsor. Dan hal ini merupakan sunnatullah, karena struktur tanah atau perbukitan tersebut akan lembut dan mudah terjadi longsor ketika turun hujan. Oleh karena itu, terjadinya suatu bencana atau musibah harus dipandang secara rasional, bukan hanya dipandang sebagai azab. ${ }^{45}$

Memang ketika membaca historisitas umat-umat yang terekam di dalam al-Qur`an bahwa musibah dan bencana yang Allah timpakan kepada mereka karena ketidaktaatan mereka. Namun berbeda dengan konteks saat inipergeseran dalam memaknai sebuah bencana juga perlu perhatikan. Mungkin dalam konteks saat ini, bencana atau musibah lebih tepat jika dimaknai sebagai cobaan untuk mengukur serta memberikan kualifikasi tingkat keimanan seseorang kepada Allah. Sehingga dengan adanya bencana atau musibah tersebut akan memberikan stimulasi gejolak internal dalam setiap individu untuk menjadi pribadi yang lebih baik.

${ }^{45}$ Abdul Mustaqim, Teologi Bencana, Jurnal Nun: Jurnal Studi Al-Qur`an Dan Tafsir di Nusantara, Vol. 1, No. 1, Tahun 2015, 106; Muhammad Alfatih Suryadilaga, Pemahaman Hadis Tentang Bencana (Sebuah Kajian Teologis Terhadap Hadis-hadis Tentang Bencana), Jurnal ESENSIA, Vol. 14, No. 1, Tahun 2013, 85-87. Bandingkan dengan Fatimahsyam, Pengintegrasian Pengurangan Resiko Bencana Dengan Pendekatan Madzhab Antroposentris, Jurnal Substantia, Vol. 20, No. 1, April 2018: UIN Ar-Raniry, Aceh. 
Namun walaupun demikian, tidak bisa dilupakan begitu saja bahwa ketika seseorang atau kelompok berlaku tidak arif terhadap lingkungan maka lingkungan tersebut pun akan menjadi 'musuh' baginya; seperti penebangan hutan dengan membabi buta akan mengakibatkan tanah longsor, pembuangan sampah yang sembarangan bisa menyebabkan banjir, pembuangan limbah dengan sembarangan bisa mengakibatkan tercemarnya lingkungan, pembakaran hutan secara liar bisa menyebabkan kebakaran dalam skala luas, sejumlah hal negatif lainnya. Oleh karena itu, di dalam QS. ar-Rum (30): $41^{46}$ diterangkan oleh Allah bahwa salah satu implikasi dari keserakahan, ketidak arifan dan ketamakan manusia terdapat alam akan menyebabkan ketidak seimbangan dan menyebabkan kerusakan di alam. ${ }^{47}$

Jadi berdasarkan eksplorasi yang telah dikemukan di atas, maka yang dimaksud dengan hukum Tuhan berbasis ketaatan di sini adalah mendudukkan suatu musibah maupun bencana sebagai stimulasi kesadaran, bahwa suatu bencana yang terjadi boleh diakui dalam setiap internal individu apakah diakui sebagai azab, teguran atau cobaan, namun juga hal itu harus memberikan efek kesadaran yang berimplikasi pada ketaatan bagi setiap individu atau kelompok yang mengalaminya.

${ }^{46}$ QS. ar-Rum (30): 41, artinya: “Telah nampak kerusakan di darat dan di laut disebabkan karena perbuatan tangan manusia, supaya Allah merasakan kepada mereka sebahagian dari (akibat) perbuatan mereka, agar mereka kembali (ke jalan yang benar)."

${ }^{47}$ M. Qurais Shihab, Tafsir Al-Misbah: Pesan, Kesan dan Keserasian AlQir an, jilid. 10 (Jakarta: Lentera Hati, 2002,),76; Ahmad Mustafa AlMaraghi, Tafsir Al-Maraghi, terj. Jilid. 8 (Semarang: Toha Putra, 1988), 330. 


\section{E. Penutup}

Bedasarkan pembahasan yang telah dieksplorasi bahwa konstruksi epistem nilai-nilai Pancasila dan Etos Sains sudah termuat di dalam al-Qur’an. Oleh karena itu, ketika nilai-nilai Pancasila dan Etos Sains benar-benar diinternalisasi dalam realitas maka secara otomatis spirit al-Qur’an juga terpribumisasikan. Karena konstruk-epistem antara ketiganya (alQur`an, Pancasila, dan Etos Sain) saling berintegrasi dan terkoneksi.

Kemudian adapun kiat aksiologis yang dapat dilakukan untuk membumisasikan al-Qur`an, yang berimplikasi juga pada pembumisasian Pancasila dan Etos Sains adalah: (1) Spirit alQur`an berbasis kemajuan yang mengusung dua prinsip: (a) Prinsif kebebasan berpikir, berinovasi, dan berkreasi; (b) Prinsip pengembangan potensi: individual dan kolektif: (2) Nilai-nilai alQur`an sebagai panoptisasi tindakan, dengan mengusung dua nilai: (a) Nilai ketuhanan, dan (b) Nilai kemanusiaan: dan (3) Konsekuensi hukum: antara hukum positif dan hukum Tuhan, yang mengusung dua model hukum: (a) Hukum positif berbasis al-Qur`an, dan (b) Hukum Tuhan berbasis ketaatan. 


\section{Daftar Pustaka}

Al-Hanafi, Ismail Haqqi, Ruhul Bayan, Beirut: Dar Al-Fikr, t.t.

Al-Maraghi, Ahmad Mustafa, Tafsir Al-Maraghi, terj. Jilid. 8, Semarang: Toha Putra, 1988.

Al-Qaththan, Manna' Khalil. Mabahits fi 'Ulum al-Qur'an, Riyadh : Ma'syurat al-'Ashr al-Hadits, 1973.

Al-Qurtubi, Al-Jami' li Ahkam al-Qur'an, Beirut: Ar-Risalah, 2006.

Atsir, Ibnu, an-Nihayah fi garib al-Hadits wa al-Atsar, jilid 2, Beirut: Dar Ma'rifat, 1991.

Az-Zabadiy, Fair, al-Qamus al-Muhith, Kairo: Dar Ibnu al-Jauzi, t.th.Az-Zamakhsyari, Tafsir al-Kasysyaf 'an Haqa`iq atTanzil wa 'Uyun 'an Aqawil fi Wujuh at-Ta'wil, Jilid I, Riyadh: Maktab al-'Abaikan, 1998.

Az-Zarqani, Manahil al-'Irfan fi 'Ulum al-Qur'an, Jilid . I, Beirut : Dar Fikr, 1988.

Fariz, Ibnu, Mu'jam Maqayis al-Lughah, Jilid . 2, Beirut: Dar alIslamiyyah, 1990.

Hamzah, Mukhotob. Studi Al-Qur'an Komprehensif, Yogjakarta: Gema Media, 2003.

Kaelan, Pendidikan Pancasila Yuridis Kenegaraan, Yogjakarta: Paradigma, 1999.

K.H.Q. Shaleh dan H.A.A. Dahlan, Asbabun Nuzul: Latar Belakang Historis Turunnya Ayat-ayat Al-Qur`an, Bandung: Diponegoro, 2000.

Kiptiyah, Embriologi dalam Al-Qur'an: Kajian Pada Proses Penciptaan Manusia, Malang: UIN Malang Press, 2007.

Mandzur, Ibnu. Lisan al-Arab. Jilid XIII, Qohirah: Dar al-Hadits, 2009.

Pasya, Ahmad Fuad. Rahiq Al-'Ilmi wa Al-Iman, terj. Muhammad Arifin, Dimensi Sains Al-Qur'an, Solo: Tiga Serangkai, 2004.

Rahman, Fazlur, Islam, New York Anchor Books, 1966.

Ramadhnai, dkk, Al-Qur'an Vs Sains Modern Menurut Zakir Naik, t.tp: Sketsa, t.t.

Sani, Ridwan Abdullah, Sains Berbasis Al-Qur`an, Jakarta: Bumi Aksara, 2015

Sari, Yunita Kartika, Studi Hadis Tentang Lalat, Skripsi Jurusan Ilmu Al-Qur`an dan Tafsir, UIN Syarif Hidayatullah, Jakarta, 2017. 
Shihab, M. Quraish, Tafsir Al-Misbah: Pesan, Kesan dan Keserasian Al-Qur`an, Jakarta: Lentera Hati, 2002. ,Membumikan Al-Qur`an: Fungsi dan Peran Wahyu dalam Kehidupan Masyarakat, Bandung: Mizan, 1992.

Sulaiman, Asep, Pancasila dan Kewarganegaraan, Bandung: Arfino Raya, 2015.

Taufiq, M. Izuddin, Dalil Anfus Al-Qur'an dan Embriologi: Ayatayat Tentang Penciptaan Manusia, Solo: Tiga Serangkai, 2006.

Tharayyarah, Nadiyah. Mausu'ah al- I'jaz al-Qur'ani, Dar alYamana, Abi Dhabi, t.t.

TIM Kemenag RI dan LIPI, Mengenal Ayat-ayat Sains di dalam Al-Qur'an.

Zuhdi, Masjfuk, Pengantar Ulumul Qur`an, Surabaya: Bina Ilmu, 1993.

Anas, Ahmad. Dkk, Dakwah Nabi Terhadap Masyarakat Madinah Perspektif Komunikasi Antar Budaya, Jurnal Ilmu Dakwah: Academic Journal for Homiletic Studies, Vol. 11, No. 1 Tahun, 2017: UIN Sunan Gunung Djati, Bandung.

Arif, Syaiful, Kontradiksi Pandangan HTI atas Pancasila, Jurnal Keamanan Nasional, Vol. 2, No. 1, 2016.

Asmasroini, Ambiro Puji, Menjaga Eksistensi Pancasila dan Penerapannya Bagi Masyarakat di Era Globalisai, Jurnal Pancasila dan Kewarganegaraan, Vol. 1, No. 2 Januari 2017.

Fatimahsyam, Pengintegrasian Pengurangan Resiko Bencana Dengan Pendekatan Madzhab Antroposentris, Jurnal Substantia, Vol. 20, No. 1, April 2018: UIN Ar-Raniry, Aceh.

Mustaqim, Abdul, Teologi Bencana, Jurnal Nun: Jurnal Studi AlQur`an dan Tafsir Di Nusantara, Vol. 1, No. 1, Tahun 2015.

Parwanto,Wendi, dan Ridwan Rosdiawan, Menggali Akar-akar Material Dakwah Lingkungan Hidup, Jurnal Al-Hikmah, IAIN Pontianak, Vol. 10, No. 1, 2016.

Rafiuddin, Mohamad. Mengenal Hizbut Tahrir: Studi Analisis Ideologi Hizbut Tahrir dan NU), Jurnal Islamuna, Vol. 2, No. 1, Juni 2015.

Said, Colle. Paradigma Pendidikan dalam Perspektif Surat Al'Alaq (96): 1-5, Jurnal Hanafa : Jurnal Studi Islamika, Vol. 13, No. 1, 2016: UIN Alauddin, Makassar. 
Struktur Epistemologi Pancasila dan Etos Sains dalam al-Qur'an: Suatu Vpaya integrasi, Interkoneksi dan Internalisasi|

Siswanto, Perspektif Amin Abdullah Tentang Integrasi Interkoneksi dalam Kajian Islam, Jurnal Teosofi, Vol. 3, No. 2, Desember, Institut Keislaman Abdul Faqih, Gersik.

Suryadilaga, M. Alfatih. Pemahaman Hadis Tentang Bencana

(Sebuah Kajian Teologis Terhadap Hadis-hadis Tentang

Bencana), Jurnal ESENSIA, Vol. 14, No. 1, Tahun 2013.

Wahid, Abdul. Al-Qur'an Sumber Peradaban, dalam Jurnal Ushuluddin, Vol. 18, No. 2, Tahun 2012, UIN Sultan Syarif Kasim: Riau.

https://id.wikipedia.org/wiki/ 